\title{
MOLECULAR IDENTIFICATION AND THERMORESISTANCE TO BOILING OF NOCARDIA FARCINICA AND NOCARDIA CYRIACIGEORGICA FROM BOVINE BULK TANK MILK
}

\author{
L.A.Z. Condas ${ }^{1}$, M.G. Ribeiro $^{1 *}$, T. Gonoi ${ }^{2}$, T. Matsuzawa ${ }^{2}$, K. Yazawa $^{2}$, R.G. Motta ${ }^{1}$, M.M.J. Franco ${ }^{1}$, F.J.P. Listoni ${ }^{1}$ \\ ${ }^{1}$ Universidade Estadual Paulista, Doenças Infecciosas de Animais Domésticos, Departamento de Higiene Veterinária e Saúde \\ Pública, Faculdade de Medicina Veterinária, Botucatu, SP, Brasil; ${ }^{2}$ Chiba University, Medical Mycology Research Center, \\ MMRC, Inohana, Chiba, Japan.
}

Submitted: October 10, 2011; Returned to authors for corrections: January 04, 2012; Approved: June 07, 2012.

\begin{abstract}
Two strains of Nocardia spp. were isolated from bovine milk of two individual bulk tank. Molecular identification classified the strains as Nocardia farcinica and Nocardia cyriacigeorgica. The thermorresistance to boiling of the isolates was carried out and was observed bacterial growth after boiling. Our findings indicate the potential risk of pathogen transmission to humans through contaminated milk with Nocardia spp.
\end{abstract}

Key words: Nocardia spp., bovine, bulk tank milk, thermoresistance, boiling

Somatic cell count from bulk tank milk (BTMSCC) is a function of the percentage of quarters infected by major pathogens in a dairy herd. Linear relationship between BTMSCC and the percentage of quarters infected with major pathogens was previously described (Rysanek et al., 2007). The identification of Staphylococcus aureus and Streptococcus agalactiae in bulk tank milk samples (BTMS) has indicate the presence of cows in the herd with infectious mastitis by these pathogens. The isolation of organisms such as coliforms, yeasts, Nocardia spp., and Streptococcus spp. (non-agalactiae) in BTMS does not necessarily indicate the occurrence of environmental mastitis, because the presence of microorganisms may be the result of direct contamination of the milk (Schoonderwoeder et al., 1990).

Nocardia spp. are environmental microorganisms in etiology of bovine mastitis. It inhabits the telluric environment and infects the mammary gland from different sources, such as: contaminated surroundings that the cows are exposed between milking periods in farms with poor hygienic management during milking, accumulated faecal material on the mammary gland, contaminated water used during milking, contaminated pre and post dipping solutions, or even contamination of the cannula during intra-mammary treatment (Ribeiro et al., 2008). $N$. asteroides, N. farcinica, N. nova and $N$. brasiliensis are recognized as the main pathogenic species in bovine mastitis (Radostits et al., 2007). Recently, the classification of genus Nocardia has been based on molecular methods, using $16 \mathrm{~S}$ rRNA gene (Kageyama et al., 2004).

Despite considered an uncommon pathogen of bovine mastitis, the identification of Nocardia spp. from mammary infections has been increasingly notified in the last years in several countries (Ollis et al., 1991; Radostitis et al., 2007),

\footnotetext{
*Corresponding Author. Mailing address: Univ. Estadual Paulista, UNESP, Infectious Diseases of Domestic Animals, Department of Veterinary Hygiene and Public Health, School of Veterinary Medicine, Botucatu, State of Sao Paulo, Brazil.; E-mail: mgribeiro@fmvz.unesp.br
} 
including in Brazil (Costa et al., 1998; Ribeiro et al., 2006; Ribeiro et al., 2008). These studies also show the importance of investigate the epidemiology of mammary nocardiosis, in order to subsidising control and preventive actions (Costa et al., 1998). The milk is considered an important source of transmission of Nocardia to humans, mainly by the consumption of raw milk and milk products or submitted to inadequate thermic treatment (Pier and Enright, 1961).

Recent studies have demonstrated the thermoresistance of Nocardia strains isolated from bovine milk (Costa et al., 1996). The boiling of milk is one of the oldest procedures used in the elimination of pathogens from milk (Furlanetto et al., 2009). However there are no preliminary studies in order to investigate the efficacy of this thermal procedure in Nocardia strains isolated from bovine milk.

Two individual bulk tank samples in the farms located at central region in State of São Paulo were collected in sterilized flasks, adequate for microbiological culture, SCC and total bacterial cell count. The results of total bacterial cell counts of these milk samples were $300.000 \mathrm{CFU} / \mathrm{mL}$ and $172 \mathrm{CFU} / \mathrm{mL}$, while the somatic cell counts were 1.966 .000 cells/mL and 890 cells/ $\mathrm{mL}$, respectively.

Both samples were submitted to microbiological culture on defibrinated sheep blood agar (5\%) and maintained in aerobic conditions, at $37^{\circ} \mathrm{C}$, for up to five days (Quinn et al., 1994). Simultaneously, the same samples were submitted to culture on agar Sabouraud-dextrose, in aerobiosis, at $37^{\circ} \mathrm{C}$, maintained for up to 15 days (Brown-Elliot et al., 2006). After 48 hours, white, dry and strongly adhered colonies were obtained. At microscopy, Gram and Kinyoun stains revealed Gram positive organisms, delicate and branched mycelial structures, with coccobacilli and filamentous forms suggestive of genus Nocardia (Quinn et al., 1994; Ribeiro et al., 2008).

Preparation of genomic DNA samples for sequencing was performed using the guanidine thiocyanate method (Kageyama et al., 2004). Nearly complete $16 \mathrm{~S}$ rRNA gene (rDNA) sequences were obtained for isolated strains. The $16 \mathrm{~S}$ rDNA was amplified and sequenced using PCR prokaryotic 16S rDNA universal primer pairs $8 \mathrm{~F}$ and $691 \mathrm{R}, 520 \mathrm{~F}$ and $1100 \mathrm{R}$, and $926 \mathrm{~F}$ and $1542 \mathrm{R}$. The strains were submitted to PCR using a DNA thermal cycler (TaKaRa Bio Inc., Japan) under followed conditions: 35 cycles at $94^{\circ} \mathrm{C}$ for 60 s for denaturation, $60^{\circ} \mathrm{C}$ for $60 \mathrm{~s}$ for primer annealing, and $72^{\circ} \mathrm{C}$ for $120 \mathrm{~s}$ primer extension. The PCR products were purified with Centri-Sep Columns (Princeton Separations Inc., USA). The DNA sequences were determined with an automatic sequence analyzer (ABI Prism 3130; Applied Biosystems Inc., Japan), using a dye terminator cycle sequencing kit (Applied Biosystems Inc.). Sequences of the 16S rRNA genes were compared against GenBank/DDBJ/EMBL database using BLAST. Sequence data of Nocardia type strains were retrieved from GenBank. Phylogenetic analysis was performed using software (MEGA ver. 4; Tamura et al., 2007) as described previously (Shibazaki et al., 2011). Sequencing analysis of the 16S rDNA segments enabled classified the organisms as Nocardia farcinica and Nocardia cyriacigeorgica. The new sequences for the isolates (strain numbers IFM 11294 and IFM 11295) were deposited to DDBJ/GenBank/EMBL with accession \# AB671776.1 and AB671777.1, respectively.

All isolates were exposed to "in vitro" evaluations to boiling conditions. The isolates were initially cultured in defibrinated sheep blood agar (5\%) and maintained in aerobiosis at $37^{\circ} \mathrm{C}$ for 72 hours. Latter, two or three typical colonies were re-suspended in $4 \mathrm{~mL}$ of sterile Mili-Q water (ultra-pure), acconditioned in tubes with the turbidity adjusted by optical density, according to the tube 1 (one) on the McFarland scale (Bier, 1984). From the suspension, the tubes were homogenized and diluted to the decimal scale $(1 / 10)$, namely: $10^{-1}, 10^{-2}, 10^{-3}$ and subsequently until $10^{-10}$. Aliquots of $0,1 \mathrm{~mL}$ were collected in duplicates and cultured in "Plate count agar"-PCA, using the "pour plate" technique, and maintained incubated in aerobiosis at $37^{\circ} \mathrm{C}$, for up to 96 hours. The colony-forming unit count - CFU was evaluated by the macroscopic visualization of the colonies on the culture media. 
The decimal dilutions that presented bacterial growth of $10^{5} \mathrm{CFU} / \mathrm{mL}$, which corresponded to the $10^{-3}$ and $10^{-2}$ dilutions, were used as inocula. Subsequently, $1 \mathrm{~mL}$ from all the isolates containing $10^{5} \mathrm{CFU} / \mathrm{mL}$ were pipetted to glass tubes closed with hydrophobic cotton and submitted to a elevation of temperature, in a bath, until it reached $100^{\circ} \mathrm{C}$ (boiling 1). For temperature measurement, a sterile thermometer was placed in one of the tubes with reference strain. The same procedure was repeated for all isolates (also containing inocula with $10^{5}$ $\mathrm{CFU} / \mathrm{mL}$ ), maintaining the tubes in the bath 1 minute after they have reached $100^{\circ} \mathrm{C}$ (boiling 2). After these, the procedure was executed again, maintaining the tubes in the bath for 5 minutes after they have reached $100^{\circ} \mathrm{C}$ (boiling 3). Aliquots of $0,01 \mathrm{~mL}$ from the tubes from all three thermal treatment groups (boiling 1,2 and 3) were submitted to microbiological culture in defibrinated sheep blood agar $(5 \%)$, in aerobiosis at $37^{\circ} \mathrm{C}$, in order to evaluate the re-isolation of strains after thermal treatment.

The thermic treatment showed that Nocardia cyriacigeorgica strain survived to boiling at $100^{\circ} \mathrm{C}$, while isolate of Nocardia farcinica survived for one minute at $100^{\circ} \mathrm{C}$.

In the individual bulk tanks from which Nocardia spp. was isolated, the SCC was higher than recommended by the Brazilian regulations of 600.000 cells $/ \mathrm{mL}$ (Brasil, 2011). A comparative analysis showed that 200.000 cells $/ \mathrm{mL}$ of CCS in individual bulk tanks corresponds to $15 \%$ of infected quarters in a herd, and 700.000 cells $/ \mathrm{mL}$ represents two thirds or more quarters infected by a pathogen (NMC, 2001). Schoonderwoerd et al. (1990) reported Nocardia genus in milk from affected quarters and from the respective individual bulk tanks (205.000 cells/mL of SCC), indicating that the origins of the agent in the tanks were the affected quarters, or contaminated utensils used in the storage of milk and the tanks. This association between SCC in the bulk tank and the Nocardia mastitis indicate the importance of evaluating the SCC in bulk tank in order to evaluate the milk quality. Furthemore, the presence of Nocardia species in bulk tank milk indicate the need of increment on dairy farms of control measures against environmental agents of bovine mastitis.

$N$. farcinica was referred as one of the main bovine mastitis causal agent in Brazilian dairy herds. However, in this study the identification of the pathogen was performed by phenotypic evaluation (Ribeiro et al., 2008). The present report described for the first time the molecular identification of $N$. farcinica in bulk tank milk from dairy herds.

$N$. cyriacigeorgica has been identified recently in other countries around $10 \%$ to $22 \%$ of the Nocardia species causing disease in humans patients (Muñoz et al., 2007; Tremblay et al., 2010; Tan et al., 2010). In Brazil, Chedid et al. (2007) studied 22 cases of immunosuppressed patients affected by nocardiosis, and $27.27 \%$ of these cases were caused by $N$. asteroides complex, to which the $N$. cyriacigeorgica species belongs. The $N$. cyriacigeorgica was recently classified based on molecular techniques (Kageyama et al., 2004). Due to this new taxonomic classification, there are no recent descriptions of infection by this specie in humans and animals in Brazil. Although the role of animals in the transmission of Nocardia to humans remains unclear, our findings indicate the potential risk of transmission of Nocardia from cows to humans by milk.

The evaluation of thermoresistance of isolates showed that the pathogen resists to boiling. Other studies have submitted isolates to inferior temperatures for longer periods, such as $45^{\circ} \mathrm{C}$ and $50{ }^{\circ} \mathrm{C}$ for up to eight hours, with bacterial growth after thermal treatment (Komaid, 2001). Likewise, $N$. asteroides isolated from bovine milk was submitted to pasteurization conditions also with bacterial growth (Costa et al., 1996). Nocardia serbivorans was described to have survived to boil (Erikson, 1955).

The present report showed that Nocardia genus has the similar behaviour of a thermoduric microorganism. Our findings indicate potential risk to human consumption of raw, pasteurized and boiled milk contaminated by Nocardia spp., especially for the immunosuppressed human patients. 


\section{ACKNOWLEDGEMENTS}

This work was supported by Fundação de Amparo à

Pesquisa do Estado de São Paulo (Fapesp), Brazil (grant numbers 2009/56037-1 and 2010/53494-5).

\section{REFERENCES}

1. Brasil. Ministério da Agricultura, Pecuária e Abastecimento. Instrução Normativa n.62. Regulamento Técnico de Produção, Identidade e Qualidade do Leite tipo A, Regulamento Técnico de Produção, Identidade e Qualidade de Leite Cru Refrigerado, Regulamento Técnico de Produção, Identidade e Qualidade do Leite pasteurizado e o Regulamento Técnico da Coleta de Leite Cru Refrigerado e seu Transporte a Granel. Brasília, 29 de dezembro de 2011.

2. Brown-Elliott, B.A.; Brown, J.M.; Conville, P.S.; Wallace, R.J. (2006). Clinical and laboratory features of the Nocardia spp. based on current molecular taxonomy. Clin. Microbiol. Rev. 19:259-282.

3. Chedid, M.B.; Chedid, M.F.; Porto, N.S.; Severo, C.B.; Severo, L.C. (2007). Nocardial infections: report of 22 cases. Rev. Inst. Med. Trop. S. Paulo 49: 239-246.

4. Costa, E.O.; Ribeiro, A.R.; Ribeiro, M.G. et al. (1996). Nocardia sp strains isolated from clinical and subclincal bovine mastitis: evaluation of the thermic resistance on the milk pasteurization (temperature/time). In: WORLD BUIATRIC CONGRESS, 19, Edinburgh, Proceedings.: 206-207.

5. Costa, E.O.; Ribeiro, A.R.; Watanabe, E.T.; Melville, P.A. (1998) Infectious bovine mastitis caused by environmental organisms. $\mathrm{Zbl}$. Veterinarmed, B, 45: 65-71.

6. Erickson, D. (1955). Therrnoduric Properties of Nocardia sebivorans and other Pathogenic Aerobic Actinomycetes. J. Gen. Microbiol. 13: 127-135

7. Furlanetto, L.V.; Souza, G.O.; Figueiredo, E.E.S.; Balian, S.C.; Pinheiro, S.R.; Telles, E.O. (2009). Avaliação da fervura na ativação de patógenos em leite integral de vaca, cabra e búfala experimentalmente contaminados. Ars Veterinaria 25: 63-67.

8. Kageyama, A.; Torikoe, N.; Yazawa, K.; Mikami, Y.; Nishimura, K. (2004). Nocardia asiatica sp. nov. pathogen isolated from patients with nocardiosis in Japan and clinical specimes from Thailand. Int. J. Syst. Evol. Microbiol. 54: 123-130

9. Komaid, A.G. (2001). Temperature resistant Nocardia biovarieties in Tucumán, Argentina. Mycopathologia 154: 57-62.

10. Muñoz, J.; Mirelis, B.; Aragón, L. M.; Gutiérrez, N.; Sánchez, F.; Español, M.; Esparcia, O.; Gurguí, M.; Domingo, P.; Coll, P. (2007). Clinical and microbiological features of nocardiosis 1997-2003. J. Med. Microbiol. 56: 545-550.

11. NMC (2001). Guidelines on Normal and Abnormal Raw Milk Based on
SCC and Signs of Clinical Mastitis. Available at: http://nmconline.org/ docs/abnmilk.pdf.

12. Ollis, G.W.; Schoonderwoerd, M.; Schipper, C. (1991). An investigation of risk factors for nocardial mastitis in central Alberta dairy herds. Can. Vet. J. 32: 227-231.

13. Pier, A.C.; Enright, J.B. (1961). Oral Infectivity and Thermal Resistance of Nocardia asteroides in Milk. Public Health Reports 76: 889-896.

14. Quinn, P.J.; Carter, M.E.; Markey, B.K.; Carter, G.R. (1994). The Actinomycetes. In:__. Clin. Vet. Microbiol. London, Wolfe, 144-155.

15. Radostitis, O.M.; Gay, C.C.; Hinchcliff, K.W.; Constable, P.D. (2007). Diseases of the mammary gland. In:_. Veterinary Medicine - A Textbook of the Diseases of Cattle, Horses, Sheep, Pigs, and Goats. 10. ed. Philadelphia, Saunders; Elsevier. 673-762.

16. Ribeiro, M.E.R.; Petrini, A. L.; Barbosa, R.S.; Zanela, M.B.; Jorge Fainé Gomes, J.F.; Stumpf Jr., W.; Schramm, R. (2006). Ocorrência de mastite causada por Nocardia spp em rebanhos de unidades de produção de leite no sul do Rio Grande do Sul. Revista Brasileira de Agrociência 12 : 471473.

17. Ribeiro, M.G.; Salerno, T.; Mattos-Guaraldi, A.L.; Camello, T.C.F.; Langoni, H.; Siqueira, A.K.; Paes, A.C.; Fernandes, M.C.; Lara, G.H.B. (2008). Nocardiosis: an overview and additional report of 28 cases in cattle and dogs. Revista do Instituto de Medicina Tropical de São Paulo, 50: $177-185$.

18. Rysanek, D.; Babak, V.; Zouharova, M. (2007). Bulk tank milk somatic cell count and sources of raw milk contamination with mastitis pathogens Veterinari Medicina, 52: 223-230

19. Santos, M.V.; Fonseca, L.F.L. (2007). Principais agentes causadores de mastite. In: __. Estratégias para controle de mastite e melhoria da qualidade do leite. São Paulo, Manole, 24-37.

20. Schoonderwoerd, M.; McFadzen, L.L.; Manninen, K.I.; Ollis, G.W.; (1990). Culturing of bulk tank milk for the presence of Nocardia spp. Can. Vet. J. 31: 453-454

21. Shibazaki, A.; Omoto, Y.; Kudo, T.; Yaguchi, T.; Saito, A.; Ando, A.; Mikami, Y.; Gonoi, T. (2011). Streptomyces coacervatus sp. nov., isolated from the intestinal tract of Armadillidium vulgare. Int. J. Syst. Evol. Microbiol. 61: 1073-7.

22. Tamura, K.; Dudley, J.; Nei, M.; Kumar, S. (2007). MEGA4: molecular evolutionary genetics analysis (MEGA) software ver. 4.0. Mol. Biol. Evol. 24: 1596-1599.

23. Tan, C.K.; Lai; C.C.; Lin, S.H.; Liao, C.H.; Chou, C.H.; Hsu H.L.; Huang, Y.T.; Hsueh, P.R. (2010). Clinical and microbiological characteristics of Nocardiosis including those caused by emerging Nocardia species in Taiwan, 1998-2008. Clin. Microbiol. Infect. 16: 966-72.

24. Tremblay, J.; Thibert, L.; Alarie, I.; Valiquette, L.; Pépin, J. (2010). Nocardiosis in Quebec, Canada, 1988-2008. Clin. Microbiol. Infect. (in press). 